\title{
DIFFERENT CONCEPTS OF STRICT LIABILITY: THE DRAFT COMMON FRAME OF REFERENCE AND THE PRINCIPLES OF EUROPEAN TORT LAW AS ROLE MODELS FOR SERBIAN LAW?
}

\begin{abstract}
Within the European Union, numerous development projects have been created with the aim of harmonizing the civil law. These projects, created as a result of the work of lawyers and research centres across Member States of the European Union, are part of the so-called "soft law" and may serve as role models for national legislators, including here the Serbian lawmaker, for regulating certain issues. Development projects touch upon practically all aspects of contemporary civil law, to a greater or lesser extent, and the emphasis in this paper is to analyse the strict liability for damage as an important form of liability for damage in the modern world, full of increased risks to people and their environment. The development projects taken as examples of how this form of liability can be regulated in different manners are the Draft Common Frame of Reference and the Principles of European Tort Law. The aim of this paper is to determine whether Serbian legislation on strict liability can be improved through the introduction of rules from these acts.
\end{abstract}

Key words: Draft Common Frame of Reference, Principles of European Tort Law, Contracts and Torts Act, general case of strict liability, special cases of strict liability.

\section{INTRODUCTION}

The purpose of development projects is in the gradual approximation of national civil legislations within the European Union and the alleviation of differences between them, which ultimately should result in the creation of a singular European civil law. ${ }^{1}$ Although the unified civil law on the European Union is still far from sight, development projects

* $\quad$ PhD Student, University of Novi Sad - Faculty of Law

e-mail: milossekulic89@gmail.com

1 For more on development projects and their character, see: Nikolić, D., 2016, Uvod u sistem građanskog prava, Novi Sad, pp. 68-71. For more on "soft law", see: Đurđev, D., 
have undoubtedly produced a significant result, most often acting as a framework, or a model according to which national legislators can upgrade their respective domestic regulations. They could represent a model towards which the Serbian legislator can progress, especially when considering the tendency of Serbia to become a member of the European Union (hereinafter also as the EU), which surely means that a certain proportion of the Serbian laws must be adapted to the legal order of the EU.

Regarding the strict liability for damage, as liability irrespective of fault $^{2}$, and as one of the salient institutes of tort law, it is useful to see how this institute is dealt with in major development projects, such as the Draft Common Frame of Reference ${ }^{3}$ (hereinafter also as the Draft) and Principles of European Tort $\mathrm{Law}^{4}$ (hereinafter also as the Principles). The discussed development projects were initiated at the initiative of the European Parliament, which on 26 May 1989 passed the Resolution on Action to Bring Into Line the Private Law of the Member States and on 6 May 1994 the Resolution on the Harmonization of Certain Sectors of the Private Law of the Member States ${ }^{5}$, both of which called on the expert community to take an active part in the process of harmonization of civil law in the European Union and the adoption of a single European Civil Code.

The Draft was published in 2008 as a result of the joint work of the Study Group on European Civil Code ${ }^{6}$ and the Research Group for Study-

2013, Soft Law u evropskom komunitarnom pravu, Zbornik radova Pravnog fakulteta u Novom Sadu, 1, pp. 101-116.

2 Strict liability represents liability irrespective of fault, i.e. this type of liability is characterized by legal irrelevance of the fault of the liable person, it is neither a condition nor ground of liability. See: Salma, J., 2009, Obligaciono pravo, Novi Sad, p. 574, and Karanikić Mirić, M., 2013, Objektivna odgovornost za štetu, Beograd, pp. 9-43. In civil law strict liability remains within the scope of non-contractual liability, i.e. tort liability, while in common law it is also contractual liability. See: Jovičić, K., Vukadinović S., 2018, Ugovorna odgovornost - pravni režimi u uporednom pravu, Teme, 2, pp. 653-656.

3 Principles, Definitions and Model Rules of European Private Law, Draft Common Frame of Reference, Outline Edition, (https://www.law.kuleuven.be/personal/ mstorme/2009_02_DCFR_OutlineEdition.pdf, 15 February 2019).

4 Principles of European Tort Law, (http://civil.udg.edu/php/biblioteca/items/283/ PETL.pdf. 15 February 2019).

5 See: Nikolić, D., 2016, p. 67.

6 The European Civil Code Study Group is an academic network composed of lawyers from the European Union countries, as well as Norway and Switzerland, dealing with comparative law in the sense of studying various regulations in the field of civil law. The ultimate goal of this group is the adoption of codified European Principles of European Law, and therefore the Draft Common Frame of Reference represents only one phase in achieving this goal. For more about the operation of the group, see: http://hwb-eup2009.mpipriv.de/index.php/Study_Group_on_a_European_Civ- 
ing Existing Private Law of the European Communities - Acquis Group. ${ }^{7}$ The Draft was created as a product of juridical science and it is an academic rather than a politically motivated text, which is also emphasized by the editors themselves, indicating that the Draft is only one of the possible text proposals for the Common Frame of Reference. The text of the Draft is extremely comprehensive and contained in ten books and annexes that regulate various civil law issues, compiled in the form of a legal text. Other sources, primarily the Principles of European Contract Law, as well as the Principles of European Law, followed by Acquis-principles and finally the results of the work of the Project Group for the Restatement of the European Insurance Contract Law were also used by the editors as a model for the adoption of this act. The expert community had divided opinions on the Draft, because of which it received a considerable criticism, including those stating that the definitions used are not consistent, that the systematization of the provisions was not carried out in a successful manner, and that it contains excessive referencing to legal standards, and too many terms from the English language, etc. ${ }^{9}$

The second analysed development project is the Principles adopted in 2005 of the European Group on Tort Law. ${ }^{10}$ The work on the Principles was extremely long and involved the preparation of a numerous preliminary studies and sending questionnaires to the Member States of the

il_Code, accessed 15 February 2019 and https://www.asil.org/eisil/study-group-european-civil-code, 15 February 2019.

7 The Research Group for Studying Existing Private Law of the European Communities was established in 2002 and today it has about 50 lawyers from most of the Member States of the EU, dealing with the systematisation of the rules of communitarian law that fall within the civil law, and which seeks to set out the rules that will form the basis of the communitarian civil law that is in the making. For more about the operation of the Group see: https://www.gbz.hu-berlin.de/research/projects/existing-ec-private-law, 15 February 2019.

8 See: Nikolić, D., 2016, p. 68.

9 On the academic character and structure of the Draft, the patterns in its adoption and the reactions of the expert community see: Dudaš, A., 2012, Od Načela evropskog ugovornog prava do Nacrta okvirnih pravila, Anali Pravnog fakulteta u Beogradu, 1, pp. 329-334 and Đurđev, D., 2013, pp. 77-81 and Đurđev, D., 2010, Nacrt zajedničkog referentnog okvira za evropsko privatno pravo iz 2009. godine, Zbornik radova Pravnog fakulteta u Novom Sadu, 2, pp. 74-76.

10 The European Group on Tort Law (formerly known as the "Tilburg Group") was formed in 1992, and it is concluded of renowned European legal scholars as well as eminent professors of law from the United States. The members of the group discuss the crucial problems of tort law and the directions of its further development, thus contributing to the harmonization of civil law in the European Union. Institutional basis for their further work is in the established European Centre for Tort and Insurance Law in Vienna. For more about the work of the Group, see: Karanikić Mirić, M., 2013, p. 17 and http://www.egtl.org/, 15 February 2019. 
European Union on the basic issues of tort law, thus creating a comparative basis as a starting point for further work. The Principles are only "a compilation of the fundamental concepts of tort law, though in the format of statutory text and at a level of detail that codifications tend to have. They are therefore not meant to be a draft code of the European tort law, nor does the Group expect that they could be implemented into any given legal system without further legislative adaptation". ${ }^{11}$ Unlike the rather extensive Draft, the Principles are much more modest, which to some extent makes sense, given that they do not go beyond the rules of the tort law, although the rules pertaining to torts are in fact significantly less numerous than those contained in the Draft. From the above, it can be concluded that the Principles have a limited impact on the harmonization of civil law in the EU, but it is comforting that the proposed regulation is more comprehensive with each new development project (the Draft was compiled subsequent to the Principles).

In the introductory part of this paper, it is worth pointing out that all relevant issues concerning the strict liability envisaged by the Draft and the Principles will be addressed, which is important, since these acts are still relatively unknown. On the other hand, there is an outlay of the solutions from the Serbian Contracts and Torts Act ${ }^{12}$ from 1978 (hereinafter also as the CTA), which regulates strict liability in Serbia.

In this way, through a comparative approach and examination of different concepts of strict liability, one may see the similarities and differences between the regulations, and whether the CTA follows the social developments and whether it can, possibly, be improved by implementing certain solutions from the Draft and the Principles.

\section{Strict Liability According to the CTA}

\subsection{GENERAL CASE OF STRICT LIABILITY}

According to the general case of strict liability, regardless of fault, one is liable for damage induced by objects or activities that result in an increased risk of damage to the surroundings (general norm of strict liability). General norm from the CTA implies that a court has authority to proclaim some object or activity dangerous in a specific litigation (regarding circumstances of each specific case) and therefore such norm is "general"

11 Koch, B., 2009, Principles of European Tort Law, King's Law Journal, 2, p. 205.

12 Contracts and Torts Act, Official Gazette of SFRY, nos. 29/78, 39/85, 45/89 - decision of the Constitutional Court of FRY and 57/89, Official Gazette of FRY, no. 31/93 and Official Gazette of SMNE, no. 1/2003 - Constitutional Charter. 
because it covers all possible dangerous objects and activities, except those explicitly prescribed by law. ${ }^{13}$ Such general case of strict liability also exists in numerous national legal systems in the EU, e.g. French ${ }^{14}$, Italian $^{15}$, Portuguese ${ }^{16}$, Croatian ${ }^{17}$, Slovenian ${ }^{18}$ and is proposed in legal reform in Austria. ${ }^{19}$ Furthermore, British judicature made certain efforts, however, still insufficient, to create general rule of strict liability ${ }^{20}$ and Swiss lawmaker also tried to enact the same rule, the attempt which failed because legal reform in this country was abandoned. ${ }^{21}$

Regarding Serbian law, this is the primary, but at the same time, in practice, the most commonly used ground when an entity is responsible for damage, regardless of fault. Key terms are, as is easily visible, a dangerous object and a dangerous activity, and the CTA does not contain any provision that would at least roughly define these terms. Yet, there are certain guidelines that make it easier for the courts to operate, specifically when it is required to identify a certain object as dangerous. In this sense, courts generally rely on the definition given by Mihailo Konstantinović, who under the dangerous object considered that movable or immovable object, which by its position or use or properties or by its mere existence represents an increased risk of danger to its surroundings. ${ }^{22}$ On the other hand, when it comes to dangerous activity, prof. Mihailo Konstantinović considered that this notion was superfluous and that the notion of dangerous objects consumed the notion of dangerous

13 Art. 154 para. 2 of the CTA. For more on the general norm of strict liability, see: Karanikić Mirić, M., 2013, pp. 15-18 and Pajtić, B., Radovanović, S., Dudaš, A., 2018, Obligaciono pravo, Novi Sad, p. 471.

14 See: Karanikić Mirić, M., 2013, p. 15. On this how the general norm of the strict liability was formed in French Civil Code and judicature, see: Pajtić, B., Radovanović, S., Dudaš, A., 2018, p. 470.

15 See: Battesini, E., 2015, Tort Law and Economic Development: Strict Liability in Legal Practice, The Latin American and Iberian Journal of Law and Economics, 1, p. 18.

16 Battesini, E., 2015, p. 18.

17 Art. 1045 para. 3 of the Contracts and Torts Act, Official Gazette of the Republic of Croatia, no. 55/2015.

18 Art. 131 para. 2 of the Obligations Code, Official Gazette of the Republic of Slovenia, no. $83 / 2001$ and $33 / 2004$.

19 See: Karanikić Mirić, M., 2013, p. 17.

20 On this how the British judicature intended to leap-frog from the traditional rule to the general rule of strict liability, see: Lubomira Kubica, M., 2016, Origins of Strict Liability for Abnormally Dangerous Activities in the United States, Rylands v. Fletcher and a General Clause of Strict Liability in the UK, International Journal of Law and Political Sciences, 3, pp. 860-881.

21 See: Karanikić Mirić, M., 2013, p. 17.

22 For more on how Mihajlo Konstantinović defined the dangerous object, Karanikić Mirić, M., 2013, p. 70. 
activity $^{23}$, but the courts in this case have made a step forward in relation to theoretical foundations, recognizing in practice cases when an activity by itself is dangerous, and that it does not necessarily have to pertain to the use of a dangerous object. Generally speaking, it can be said that a dangerous activity is such activity, the regular or usual performance of which creates an increased risk of damage to the surroundings.

What can be noticed is that over time, the scope of objects and activities that are considered dangerous is expanding, so dangerous objects now encompass an improperly parked motor vehicle, steam locomotive, flowerpot on the terrace of a multi-storey building, etc., and dangerous activities are, for example, working in the mine (the mine as such is not a dangerous object nor is any part of an equipment that a miner uses, but working in mine often exposes a miner to increased risk of damage in case of mine collapse, for example), conductor service (in case of drunk passengers or sport fans, for example), etc. ${ }^{24} \mathrm{~A}$ conclusion may be reached that there is a really large scale of objects if used in a certain way or placed in a certain position may represent dangerous objects, and also that many activities according to the mode of execution can be dangerous. Courts are those who have a wide authority to determine in each case whether there is an increased risk of harm, and they are those who classify an object or activity as dangerous, and therefore it can be said that in Serbian law there is no numerus clausus of dangerous objects, and dangerous activities, but open-ended definition of dangerous object and dangerous activity.

\subsection{CONDITIONS, PARTIES AND DEFENCES}

There are three conditions that must be fulfilled if someone is to be subjected to the strict liability according to the CTA. First of all, there must be a dangerous object or a dangerous activity which arises the risk of damage, then it is necessary that the damage is incurred (except in case of liability for emissions when the mere risk of damage occurrence threat is sufficient), whether it is a pecuniary or non-pecuniary damage and, ultimately, there must be a causal relationship between dangerous object or dangerous activity and the damage. The CTA provides for rebuttable presumption of causal relationship (in relation to these cause-effect relationships presupposes its existence, but this presumption is rebuttable and the burden of proof of the opposite is on the subject of strict liability). ${ }^{25}$

23 Karanikić Mirić, M., 2013, pp. 84-85.

24 See: Salma, J., 2009, pp. 577-583.

25 Art. 173 of the CTA. 
For the damage from the dangerous object, its holder ${ }^{26}$ is liable, and for the damage from the dangerous activity the person who is performing it, i.e. the operator. ${ }^{27}$ These are persons primarily liable for the damage, regardless of their fault. The concept of a dangerous object's holder can be determined according to an objective or subjective criterion. According to an objective criterion, the holder is a person who has a certain in rem right in relation to a dangerous object, most commonly ownership right or a right of a narrower scope, whereas according to a subjective criterion that person exercises factual control over a dangerous object and who has the ability to exercise his will on this object, the possessor. The subjective criterion is primary and on the other hand the objective one is additional and has corrective function, that is it creates an indication that the title-holder of a certain in rem right exercised factual control over a dangerous object. Only if there are no different information regarding factual control over a dangerous object in sense of the subjective criterion, presumption that certain title-holder exercises factual control over a dangerous object can be made (usage of the objective criterion). ${ }^{28}$ As far as the person dealing with dangerous activity is concerned, it is understood that he/she is involved in performing activities that result in an increased risk of harm, and this must not necessarily be a registered and economic activity.

There is no strict liability if the above listed conditions are not fulfilled, and the holder of a dangerous object can be exonerated if he proves the damage was caused by force majeure (unforeseeable, unavoidable and inevitable external event from an objective aspect), the actions of a third party or the actions of the injured party (active act or omissions), which actions must also be unforeseeable, unavoidable and inevitable. A partial exoneration from strict liability is available if the injured party contributes to the occurrence of the damage, but when a third person has done so, he/she will be liable jointly and severally with the holder of a dangerous object, and shall be liable in proportion to the gravity of his/her fault. ${ }^{29}$

\subsection{OTHER IMPORTANT CASES OF STRICT LIABILITY}

The CTA specifically regulates liability for emissions as a specific form of strict liability. What distinguishes liability for emissions from classical strict liability is that, in the case of emissions, the damage does not have to occur, it will only be sufficient for the risk to the physical integrity

26 Although the CTA uses the term "holder", in literature there is an opinion that this term is synonym with the term "posessor". See Karanikić Mirić, M., 2013, p. 96.

27 Art. 174 of the CTA.

28 See: Karanikić Mirić, M., 2013, pp. 94-99.

29 Art. 177 of the CTA. 
of people and their property to exist. The CTA prescribes that anyone may require from another to remove a source of danger from which significant damage may be inflicted to him/her or an unspecified number of persons, and to refrain from activities that cause harassment or danger of damage if the occurrence of nuisance or damage cannot be prevented by appropriate measures. On the basis of the request of an interested person, the court may order appropriate measures to be taken to prevent the occurrence of damage or nuisance, or to eliminate the source of danger, at the expense of the holder of the source, if he/she himself does not do so. Hence, when discussing liability for emissions, it can be said that, since the risk of damage exists, the sense of emission liability is in prevention, in other words to preclude the occurrence of damage, as CTA prescribes in aforementioned possibilities. ${ }^{30}$ Finally, CTA prescribes that compensation can only be awarded if the damage exceeds the permitted limits and if damage stems from a concessional emission activity. ${ }^{31}$

Liability in the event of an accident caused by a motor vehicle on the move is prescribed in the CTA in the section regulating strict liability, and yet, although a motor vehicle on the move is undoubtedly a dangerous object, it cannot be said that this is a pure example of strict liability, but rather a combination of rules on fault-based and strict liability. The CTA envisages two legal regimes, one between the holders ${ }^{32}$ of motor vehicles and the other between the holders of motor vehicles and third parties. First, if an accident involving a motor vehicle on the move is caused by the sole fault of one holder, and the damage is inflicted to the other, the rules on fault-based liability apply, and if the fault is mutual, each holder is liable for the total damage they suffered in proportion to their fault. Only in the last case of liability for damages inflicted on another motor vehicle holder, if there is no fault of anyone, the holders are equally liable if the reasons of justice do not require anything else (there is strict liability). On the other hand, when it comes to liability for damage caused to third parties, motor vehicle holders are liable jointly and severally, based on the principle of strict liability. ${ }^{33}$ The rules laid down are shall apply only if the damage is caused by a traffic accident, i.e. if there was a collision between two motor vehicles. In all other cases, not involving a collision of two or more motor vehicle (by hitting a pedestrian, guardrail, etc.), the motor vehicle should be treated as a dangerous thing, which means the application of the general rules on strict liability.

\footnotetext{
30 See: Salma, J., 2009, pp. 472-477.

31 Art. 156 of the CTA.

32 See: footnote 26 of this paper.

33 Art. 178 of the CTA.
} 
Regarding the liability of the producer of a defective thing, it can be said that it also refers to the form of liability classified in the CTA section that prescribed strict liability, but it is again a combination of rules of fault-based and strict liability. ${ }^{34}$ In the first case, if the producer did not know about the defect of the thing he produced and put into circulation, and the deficiency of which poses a risk of harm to persons or objects, the producer will be liable for the damage that would result from that deficiency, regardless of his fault. In the second case, if the producer did not take all necessary measures to prevent damage, which he could foresee, by deploying warning, safe packaging or other appropriate measure, he is also liable for the dangerous characteristics of the thing, but now his liability is based on his fault. ${ }^{35}$ In the field of consumer law, Serbia also adopted lex specialis in the form of the Consumer Protection Act. ${ }^{36}$ The said Act applies only as a special case when the producer of a defective product is a trader, then it is necessary that the damage is inflicted on a natural person and that it is a property damage due to death, bodily injury or destruction or damage to the property that the injured person usually used for personal use or consumption. ${ }^{37}$ Under this Act, a responsible person is always liable for the damage caused, regardless of his/her fault.

Strict liability can also arise in the context of responsibility for the other. This is precisely the case with the employer's liability for damage caused by his employee. According to a solution of the CTA, the company in which the employee worked at the moment of the occurrence of damage is liable for the damage caused by the employee to a third person, at work, or in connection with work, unless it proves that the employee has acted properly in the given circumstances. The liability of the company is not fault-based because no fault on behalf of the company as a separate legal entity can exist and therefore is not required for company's liability; however the fault of the employee is a precondition for the existence of strict liability of the company. Employee deliberately causing damage gives the injured party the possibility to claim damage directly from the employee, and the company has a recourse claim towards the employee if the damage was compensated and the employee caused it intentionally or with gross negligence. All stated in respect of the liability of the compa-

34 In the literature, there are also different perceptions according to which the producer of defective objects is purely strictly liability. See: Karanikić Mirić, M., 2013, pp. 191-198. Nevertheless, the dominant view is that it is a mixed form of liability. See: Salma, J., 2009, p. 597 and Pajtić, B., Radovanović, S., Dudaš, A., 2018, p. 487.

35 Art. 179 of the CTA.

36 Consumer Protection Act, Official Gazette of RS, no. 62/2014.

37 On the scope of applicability of the Consumer Protection Act, see: Karanikić Mirić, M., 2013, p. 195. 
ny is applicable for any other employer. ${ }^{38}$ For damage caused by dangerous objects or dangerous activities, the employer is liable irrespectively of fault ${ }^{39}$, and this form of liability has already been discussed above.

Liability of a legal entity for the damage caused by its body is also a case of liability for the acts of others, which will exist when a body of a legal entity caused damage to a third party in the exercise or in connection with the performance of its functions. The same as in the case of the employer's liability for damage caused by an employee, there is a recourse claim of a legal entity towards its body. ${ }^{40}$

When it comes to parents' liability for damage caused by a minor below the age of seven, it can be noticed that Serbian law in this case is an exception $^{41}$ in relation to what is common in national legal systems in Europe, that is that the liability of the parents for the damage their child caused is fault-based liability with the presumption of fault. Namely, when the damage has been caused by a minor below the age of seven, his/her parents are liable for the damage, regardless of the fault. Beside general defences, parents can also be relieved from liability if a child was entrusted to another person (e.g. school), in which case other person shall be liable for damage.

These are not all cases of strict liability, only the important ones. The CTA also provides for liability arising from terrorist acts, public demonstrations or manifestations ${ }^{42}$, liability of the event organizer ${ }^{43}$, liability for the obligation to conclude a contract ${ }^{44}$ and liability in connection with the performance of tasks of general interest ${ }^{45}$ (most often utilities activities). However, these cases are less significant and are not examined in this paper.

\section{Strict Liability According to the Draft}

The Draft knows nothing of the general case of strict liability, but instead envisages a number of special cases, thus compensating for the lack of a general norm. In addition, the Draft permits an attribution of addi-

38 Art. 171 of the CTA.

39 Art. 170 of the CTA.

40 Art. 172 of the CTA.

41 The same exemption exists in minority of other national legal systems in Europe, such as in Croatian law - Art. 1056 of the Croatian Contracts and Torts Act and in Slovenian law - Art. 142 of the Slovenian Obligations Code.

42 Art. 180 of the CTA.

43 Art. 181 of the CTA.

44 Art. 183 of the CTA.

45 Art. 184 of the CTA. 
tional cases of strict liability, other than those specifically stated, and in that sense the solution from the Draft constitutes an "open-ended" system.

\subsection{LIABILITY FOR DAMAGE CAUSED BY EMPLOYEES AND REPRESENTATIVES}

This liability is the only example of liability for the acts of others from the Draft that is strict. A person who employs or similarly engages another person is accountable for the causation of legally relevant damage suffered by a third person when the person employed or engaged caused the damage in the course of the employment or engagement and caused the damage intentionally or negligently, or is otherwise accountable for the causation of the damage. Neither the employer, nor a person who similarly engaged someone, or another employee and similarly engaged cannot be considered a third person here. ${ }^{46}$ It is clear that a responsible person may first and foremost be the employer, but it is controversial what is considered under "similar engagement". The Handbook for the Draft Common Frame of Reference (hereinafter: the Handbook) addresses this dilemma and states that similar engagement is "relationship of instructional dependence (or superiority and inferiority), out of which flows an authority on the part of the liable person to control the conduct of the relevant acting party" 47 (e.g. the engagement of a lawyer for a specific task, a hospital surgeon for certain operations, etc.). When it comes to similar engagement, it should also be noted that the length of the engagement itself is not decisive when it comes to this form of liability, which will exist even when the damage was caused by the person performing temporary work. ${ }^{48}$

Certain conditions must be met if the employer or the person who similarly engaged someone are to be liable for the damage, regardless of their fault. Firstly, a legally relevant damage must arise, then there must be a causal relationship between the damage incurred and the performance of the work under employment or similar engagement, and finally, it is necessary that the employee or a person who are in some other way engaged in work are at fault of inflicting damage, which is therefore a condition of this liability. This rule does not affect liability of the employee himself from whom the injured party can always claim damage compen-

46 See: Principles, Definitions and Model Rules of European Private Law, Draft Common Frame of Reference (DCFR), Full Edition, Munich, 2009, p. 3454.

47 Principles, Definitions and Model Rules of European Private Law, Draft Common Frame of Reference (DCFR), Full Edition, 2009, p. 3455.

48 Principles, Definitions and Model Rules of European Private Law, Draft Common Frame of Reference (DCFR), Full Edition, 2009, p. 3457. 
sation under a fault-based liability ${ }^{49}$, and may at last claim compensation for damage from both the employee and the employer as joint and several debtors. ${ }^{50}$ The same principle applies when the damage is caused by a person who is similarly engaged.

Everything that has been said about this type of liability also applies to liability of a legal person for the damage caused by its representative in the course of his/her engagement. The term representative entails a person who is authorised to effect juridical acts on behalf of the legal person by its constitution. ${ }^{51}$

\subsection{LIABILITY FOR DAMAGE CAUSED BY UNSAFE STATE OF AN IMMOVABLE}

By providing for liability for damage caused by unsafe state of an immovable, the Draft builds up on the roots and the historical development of strict liability, as immovables were among the first dangerous objects. According to the Draft, it is considered that the immovable is unsafe if it does not ensure such safety as a person in or near the immovable is entitled to expect, considering the circumstances such as the nature of the immovable, access to it and the cost of avoiding the immovable being in that state. Therefore, the Draft lists some parameters that are to be taken into account when assessing the safety of an immovable, but according to the circumstances of the case, some others may be taken into consideration. Certainly, the costs of avoiding the immovable being in unsafe state are the most interesting parameter. With respect to the said costs, the Handbook states that it must be in a reasonable proportion to the type of risk, whereby "more must be done to protect against dangers to life and limb than to protect against dangers to property". ${ }^{2}$ Regarding the nature of an immovable, it is important to consider the type of land or type of building, as well as the type of risk they create, and in terms of access to the immovable, it is necessary to distinguish the case where people are called by the responsible person to access the immovable from the case when they approach contrary to his/her will, when the standard of immovable safety is considerably lower. ${ }^{53}$ In any case, whatever criteria apply to the safety of an immovable, it is always done from the aspect of a person suffering the damage, albeit such an assessment is by no means subjective,

49 For more on the liability of the employee according to the Draft, see: Art. VI.-7:104 of the Draft.

50 See: Handbook, p. 3459.

51 Art. VI.-3:201. of the Draft.

52 Handbook, p. 3482.

53 Handbook, p. 3482. 
but objectively observing what a reasonable person would expect in terms of safety of an immovable, while taking into account the circumstances of the case. ${ }^{54}$ The next question to consider is who is the responsible person. Strict liability for the damage caused by the unsafe immovable is on the part of the person who independently exercises control over the immovable (i.e. exercises his/her will) ${ }^{55}$, and it is considered that somebody independently exercises control over the immovable, if it is a matter of such control which reasonably imposes a duty on that person to prevent the legally relevant damage. In the first place, the responsible person is the owner of the immovable, because he/she in most cases exercises control over the immovable. The Draft, moreover, presumes that the owner independently exercises control over the immovable, but this presumption is refutable and the owner himself can prove that another person is doing so. Therefore, the Draft puts the owner of the immovable into the forefront, but does not accept the concept of ownership completely when determining the notion of the responsible person because, in addition to the owner, equally as the owner, any other person who independently exercises control over the immovable (e.g. a lessor or builder of immovable in construction) shall be held liable for damage resulting from unsafe condition of an immovable. What is also important to note is that the drafters of the Draft did not provide for liability of the keeper of an immovable, although the concept of the keeper as a responsible person has been adopted when it comes to liability for damage caused by a motor vehicle, liability for damage caused by animals and liability for damage caused by dangerous substances or emissions. ${ }^{56}$ In this regard, the Handbook states that "the situation for immovables is distinguishable from that of motor vehicles or animals because with immovables (e.g. large buildings) different parts may be under the control of different persons. The concept of a keeper is not designed to cover such situations". ${ }^{57}$ Finally, the Draft narrows down the notion of legally relevant damage in the context of this form of strict liability, and therefore the responsible person, regardless of fault, is liable only for the economic or non-economic damage caused to another in the form of personal injury, for consequential loss (e.g. medical treatment costs), loss suffered by third persons as a result of another's personal injury or death ${ }^{58}$, as well as for loss resulting from property damage (other

54 Handbook, p. 3481.

55 For more on executing control, see: Vodinelić, V.V., 2014, Građansko pravo: Uvod u građansko pravo i opšti deo građanskog prava, Beograd, p. 214.

56 See: Handbook, pp. 3482-3483.

57 Handbook, p. 3483.

58 Damage suffered by a third person due to somebody's death or somebody's bodily injury is thought of as a non-pecuniary damage arising from the close relationship 
than to the immovable itself). ${ }^{59}$ Other forms of damage (damage resulted from a non-performance of contractual obligations, the loss or injury resulted from a violation of a right otherwise conferred by law or the loss or injury resulted from a violation of an interest worthy of legal protection ${ }^{60}$ ) are not covered by this case of strict liability, which means that if one of these other forms of damage arose due to the unsafe state of the immovable, the liability shall be conditioned as the fault of the responsible person (fault-based liability). The same principle applies in all other cases of strict liability from the Draft.

\subsection{LIABILITY FOR DAMAGE CAUSED BY ANIMALS}

The Draft does not specify the term "animal" and definition of that term is necessary in order to be able to speak at all about liability for damage caused by animals, which is, beside the liability for the damage caused by the unsafe state of an immovable, incorporated into the Draft as a homage to the historical development of strict liability, given that animals, in addition to immovables, were among the first dangerous objects. In the absence of a definition from the Draft itself, the Handbook is of great importance, according to which no distinction is made between pets and animals kept for economic purposes, domestic and wild animals. Although the concept of an animal is understood very broadly, it does not include microorganisms (which will be referred to under strict liability for damage caused by dangerous substances or emissions) and wild animals living in the wild (the Draft does not contain any specific rules on person liable for damage caused by wildlife in wild), but only those that are kept. ${ }^{61}$ The person liable for the damage caused by an animal is its keeper ${ }^{62}$, and it means "a person who has the beneficial use or physical control of it for that person's own benefit, and who exercises the right to control it or its use". ${ }^{63}$ Although the Draft opted for the concept of the keeper, certainly one of the basic indicators that someone is a keeper is the ownership of an animal. The owner of the animal is usually its keeper, but these are not the same terms, so it is possible that someone is considered an ani-

of the person primarily injured (the one who died or who was physically injured) and the third person, in other words indirectly injured. For more about this form of damage, see: Art. VI.-3: 202. of the Draft and Handbook, pp. 3224-3229.

59 Art. VI.-3:202. of the Draft.

60 Art. VI.-2:101 of the Draft

61 See: Handbook, pp. 3494-3496.

62 Art. VI.-3:203. of the Draft.

63 The concept of a keeper is essential for the field of non-contractual liability for damage, and the notion of ownership is the notion of property law and its meaning varies from one state to another. Handbook, p. 3496. 
mal keeper, although at the same time he is not its owner (for example, if someone borrowed a horse he will be considered a keeper even if he is not the owner). It is also important to say that it is necessary for one to use an animal or hold it in his possession for his own purposes over a long period of time, in order for one to be able to at all express his right to control over an animal (e. g., Handbook states that "a person who rents a horse to ride at stables is not its keeper. A short-term loan by a keeper to another for that other's use does not mean that the existing keeper will lose the status of keeper. Conversely, a stable which competes at tournaments and to which a horse is rented for use in tournament events for two years is keeper during this time"64). If there are several owners of an animal, they are in that case responsible as joint and several debtors. ${ }^{65} \mathrm{~A}$ keeper of an animal is also a person who unlawfully seized the animal, except when the "real" keeper did not take everything that could be done to prevent unlawful confiscation, in which case he is liable for the damage under the fault-based criterion.

\subsection{LIABILITY FOR DAMAGE CAUSED BY DEFECTIVE PRODUCTS}

When analysing the solutions from the Draft regarding liability for damage caused by defective products, it is necessary to start from the concept of the product. The term product encompasses a movable, even if incorporated into another movable or immovable, or electricity. Product deficiency exists if a product does not provide the safety which a person is entitled to expect having regard to the circumstances including the presentation of the product, the use to which it could reasonably be expected that the product would be put and the time when product was put into circulation. What the Draft specifically emphasizes is that it will not be considered that the product has a defect only because it was replaced on the market by a better product. In this way, the Draft allows for economic development, the creation of better products, but also prevents potential abuses by consumers in terms of the realization of the right to compensation. Regarding person liable for damage, first, this may be the producer, which is understood to be in the case of a finished product or a component, the manufacturer, in the case of raw material, the person who abstracts or wins it and generally any person who, by putting a name, trade mark or other distinguishing feature on the product, gives the impression being its producer. Then, liability equal as the producer's, lies on a person who imported the product into the European Economic Area for sale, hire,

64 Handbook, p. 3947.

65 Handbook, pp. 3496-3497. 
leasing or distribution in the course of that person's business. Finally, there is also the supplier's liability under the same rules, but it is limited and in the first case only exists if the producer cannot be identified, and in the second, when it comes to the imported product, if the product does not indicate the identity of the importer (whether or not the producer's name is indicated), unless the supplier informs the person suffering the damage, within a reasonable time, of the identity of the producer or the person who supplied that supplier with the product. In addition to the general cases of exclusion from liability from the Draft that will be discussed later, the Draft introduces here also certain special ones. ${ }^{66}$ The special case that draws the most attention is the case when scientific and technological knowledge at the time of placing the product into circulation did not allow it to be discovered - development risks. Development risks could be defined as conceivable defects, i.e. defects of products that were discovered after placing the product on the market, which at the time of the product marketization could not have been detected because the state of science and technology was not at the level that allowed it. They are of great importance because they allow producers to be progressive, to create modern, sophisticated products and to research, providing them defence in case of damage caused by a product's inconceivable defect. ${ }^{67} \mathrm{On}$ the other hand, the Draft has made the damage caused by the defective product stricter, insofar as it is prescribed that it cannot be contractually excluded or restricted. ${ }^{68}$

\subsection{LIABILITY FOR DAMAGE CAUSED BY A MOTOR VEHICLE}

With regards to the liability for damage caused by a motor vehicle, the Draft envisages the concept of a motor vehicle that includes any vehicle intended for travel on land and propelled by mechanical power, but not running on rails, and any trailer, whether or not coupled. For damage

66 Art. VI.-3:204. of the Draft.

67 Of all the aforementioned grounds for releasing liability, only this one is characterized by the non-existence of harmonized opinions, and controversies that accompany development risks remain the subject of scientific debate. What are the development risks, what is their significance in the domain of the liability of the producers of defective products and whether they change the character of this form of liability, see: Sekulić, M., 2018, Development Risks - Definition Under European Union Law and Justification for Implementation in Serbian Law, Zbornik radova Pravnog fakulteta u Novom Sadu, 2, pp. 799-817, Linger, L., 1990, The Product Liability Directive: A Mandatory Development Risks Defence, Fordham International Law Journal, 2, pp. 478-509. and Hodges, C., 1998, Development Risks: Unanswered Questions, The Modern Law Review, 4, pp. 560-570.

Art. VI.-5:401. of the Draft. 
that arose in a traffic accident, which occurred through the use of a motor vehicle, the keeper of the motor vehicle is liable, and the term "keeper" here has the same meaning as stated before in the context of animal keeper. If someone unlawfully seized a motor vehicle, he/she will be considered a keeper and will not be liable for damage only if the "real" keeper failed to do everything he could to prevent unlawful confiscation. In this case, liability of the real keeper shall be fault-based. The Draft does not prescribe strict liability of the driver if he is not at the same time a keeper, which means that the driver will always be subject to the general rules of fault-based liability. ${ }^{69}$ Apart from limiting the legally relevant damage to the listed forms, the Draft also requires that the damage arises from a traffic accident that occurred with the use of a motor vehicle ${ }^{70}$, which implies that liability for damage caused by a motor vehicle will exist only when it is used on a public road or a road that is available for the use by motor vehicles. The use of a motor vehicle usually involves driving, but this does not necessarily have to be the case, so it is possible that the owner is strictly liable for the damage also when he parked the vehicle on a public road or a road that is available for the use by motor vehicles. ${ }^{71}$

\subsection{LIABILITY FOR DAMAGE CAUSED BY DANGEROUS SUBSTANCES OR EMISSIONS}

Awareness of the need for environmental protection has found its expression in the Draft in the form of providing for liability for damage caused by dangerous substances or emissions. According to the Draft, substances are chemicals (whether solid, liquid or gaseous) and microorganisms are to be treated like substances. By nature, dangerous substances are substances that have certain hazardous characteristics that are capable of causing harm to people and their property. On the other hand, emissions are the release or escape of substances, the conduction of electricity, heat, light and other radiation, noise and other vibrations and other incorporeal impact on the environment. Emissions are connected with certain installations through which they are being channelled, and installation can be mobile, under construction or not in use. Concepts of substances, emissions and installations are defined by the Draft itself. Liability for damage caused by dangerous substances or emissions is on the side of the keeper of the substance or the installation operator, however, those persons will be exonerated if they do not keep the substance or operate the installation

69 See: Handbook, pp. 3525-3526.

70 Art. VI.-3:205. of the Draft.

71 See: Handbook, p. 3526. 
for purposes related to that person's trade, business or profession or show that there was no failure to comply with statutory standards of control of the substance or management of the installation. Therefore, in addition to the general ones, the Draft here also provides for specific defences. ${ }^{72}$

\subsection{CONDITIONS, PARTIES AND DEFENCES}

Regarding conditions that must be met in order for strict liability to arise, it is clear that there is no strict liability if there are no dangerous objects (e.g. unsafe immovable, defective products, etc.) or dangerous activities (e.g. the conduction of electricity, etc.) and if no damage has occurred. What the Draft is expressing is the existence of a causal relationship between a certain dangerous object or a dangerous activity and the resulting damage. Namely, it is considered that a particular person causes legally relevant damage to another if the damage is to be regarded as a consequence of danger for which that person is responsible ${ }^{73}$, with the Draft here not creating the presumption of a causal relationship, which needs to be proved. In accordance with the foregoing, we can conclude that there are three conditions for the existence of strict liability in all cases listed in the Draft.

The person strictly liable for damage is the person who is responsible for the source of the increased danger from which the damage arose. This is a general rule that is elaborated in each individual case of strict liability, when person liable for damage is defined more precisely. From the analysed solutions it can be noted that the strictly liable can be a person who independently exercises control over an immovable, the keeper of an animal, motor vehicle or dangerous substances, the installation operator, as well as the producer, the supplier or importer of a defective product.

There is no strict liability if the abovementioned conditions are not fulfilled. In addition, there are numerous defences available for a tortfeasor.

First of all, exoneration of the person strictly liable for damage may result out of a valid consent of the victim to suffer damage, such consent implying acceptance of the risk of damage ${ }^{74}$ (usually in the context of martial arts or other dangerous sports), and it should be pointed out that only the consent of the injured person, who has all the information regarding the occurrence of the damage and which is given lucidly, is a valid consent. ${ }^{75}$

\footnotetext{
72 Art. VI.-3:206. of the Draft.

73 Art. VI.-4:101. of the Draft.

74 Art. VI.-5:101. of the Draft.

75 See: Handbook, pp. 3608-3614
} 
In addition, the victim's contributory fault can lead to a limitation of strict liability, but this fault must not be insubstantial. If the damage is caused in a traffic accident, only the profound failure of the victim in relation to its own safety can be the basis for the exoneration. ${ }^{76}$

Operating within authority conferred by law also leads to the exemption from strict liability ${ }^{77}$, whereby this applies only to private-law entities and not to police officers and other persons who act in a public capacity. ${ }^{78}$

When damage is caused by self-defence in reasonable protection of a right or of an interest worthy of legal protection of that person or a third person, the person who acted in self-defence will not be liable for damage done if it was the victim who endangered the right or interest protected. In the case of benevolent intervention, the intervener shall not be liable for the damage caused to the principal of the business if there was no breach of the intervener's duties. A peculiar solution from the Draft states that in the event of a necessity, that is, the situation of imminent danger to life, body, health or liberty of another person, such necessity does not lead to total exemption from strict liability, it only reduces the obligation to compensate the damage to a reasonable extent. ${ }^{79}$

Protecting fundamental values in a democratic society, such as freedom of expression or freedom of assembly, leads to the exculpation of strict liability, especially when the damage is caused by the dissemination of information in the media. ${ }^{80}$ Therefore, the Draft protects the freedom of the press, which will not be exempted from strict liability in case of spreading fake news or mere rumours. ${ }^{81}$

The next basis for limiting strict liability is mental incompetence at the time of causing damage, but only if such a solution is equitable taking into account the financial means of the person who would otherwise be responsible and the other circumstances of the case. If the reasons of justice so require, a mentally incompetent person will be obliged to compensate for the damage to a reasonable extent. ${ }^{82}$

Finally, force majeure ${ }^{83}$ leads to the release from strict liability, and implies an abnormal event which cannot be averted by any reasonable

76 Art. VI.-5:102. of the Draft.

77 Art. VI.-5:201. of the Draft.

78 See: Handbook, pp. 3659-3661.

79 Art. VI.-5:202. of the Draft.

80 Art. VI.-5:203. of the Draft.

81 See: Handbook, pp. 3680-3681.

82 Art. VI.-5:301. of the Draft.

83 The Draft uses term "event beyond control". 
measure and which is not to be regarded as a result of the conduct of a person who would otherwise be held accountable. ${ }^{84}$

A contractual exclusion or limitation of strict liability is permitted in the Draft in all cases, except in one case - liability for damage caused by the defective product. ${ }^{85}$

\section{Strict Liability According to the Principles}

The most controversy among the members of the European Group for Tort Law during the drafting of the Principles has arisen in connection to the formulation of strict liability. The initial idea was a widely-defined rule of strict liability that would be so flexible that it could include many risks of damage incidents regardless of fault. ${ }^{86}$ However, as there were many contradictory opinions, the members of the Group eventually agreed to introduce in the Principles a narrow general rule that would cover only the cases of extreme risks. ${ }^{87}$

\subsection{GENERAL CASE OF STRICT LIABILITY PERTAINING TO ABNORMALLY DANGEROUS ACTIVITY}

The Principles relates to the strict liability for the general concept of activity from which the increased risk of damage arises and such activity is the one that creates a foreseeable and highly significant risk of damage, even when all due care is exercised in its management, provided that it is not an activity that is a matter of common usage (abnormally dangerous activity). When assessing the potential of the risk of damage, which is relevant for the notion of dangerous activity, the seriousness of the damage and the likelihood of its occurrence shall be taken into account. This liability lies with person who carries on an abnormally dangerous activity, and of course it is required that the damage was really caused by that activity, that is, it has come from the characteristic risk that conducting such activity carries. ${ }^{88}$ Explained concept of strict liability in the Principles is actually general case of strict liability.

The fact that the Principles require that abnormally dangerous activity be an uncommon activity, that is, an activity that is not undertaken on

84 Art. VI.-5:302. of the Draft.

85 Art. VI.-5:401. of the Draft.

86 See: Koch, 2009, p. 211.

87 Koch, 2009, p. 211.

88 Art. 5:101. of the Principles. 
a daily basis and which is not a general practice, further narrows the scope of the general rule presented. Such restriction of strict liability to uncommon activities does not exist in any national legal system within the EU. ${ }^{89}$ For this kind of restriction, most of the traffic accidents could not be subsumed under the above explained general rule, although in almost all European legal systems motor vehicle owners are liable for damages incurred in the traffic accident regardless of their fault. ${ }^{90}$ Such an unsuitable solution can, however, be circumvented by specifying special cases when one is liable for damage, regardless of fault.

\subsection{STRICT LIABILITY IN OTHER CASES}

Although the Principles primarily relate to strict liability from an abnormally dangerous activity, they allow for other special cases to be prescribed, and this can also be done in the Principles (although there are no such cases for the time being), then in national law, as well as in international conventions. In that case, the general rule on strict liability from the Principles does not apply ${ }^{91}$, which means that the Principles are based on the premise that in these special cases special rules will be formulated that will answer the question of what is the source of increased danger that caused the damage and who is responsible for the compensation for damage. Therefore, it can be said that the Principles leave the possibility of extending the scope of the application of strict liability through creation of specific norms, and in a more indirect way they permit for the extension of a narrow concept of abnormally dangerous activity which the existing general rule unnecessarily limits. Hence the dangerous activity must not necessarily be qualified as the one that creates an abnormal risk of damage. ${ }^{92}$

\subsection{DEFENCES}

The Principles do not explicitly state the conditions that must be fulfilled for strict liability to arise, but they can be deducted by carefully analysing the text of the Principles. Namely, it is evident that there must first be an activity that results in an increased risk of harm, which activity is clearly stated in the Principles, and it is also necessary that the damage

89 Shavell S., The Mistaken Restriction of Strict Liability to Uncommon Activities, Journal of Legal Analysis, 1/2018, pp. 7-9.

90 See: Koch, B., 2009, p. 211.

91 Art. 5:101. of the Principles.

92 Art. 5:102. of the Principles. 
has occurred, and it should be pointed out that the Principles do not restrict the notion of legally relevant damage to that for which one is liable regardless of fault, as it appears in the Draft. Finally, an appropriate causal relationship is also required between the dangerous activity and damage, which is not presumed, but has to be proven, or as it is stated in the Principles, that the damage resulted from the risk that conducting an activity carries. All this is in accordance with the general standard from the Principles that the activity is a cause of the victim's damage if, in the absence of the activity, the damage would not have occurred. ${ }^{93}$

Strict liability is excluded if the conditions for its existence are not fulfilled, and the Principles prescribe when there is also an exemption from it. The first case is a force majeure, and the second is a third-party action. These external factors can limit the liability of operator of a dangerous activity, and to what extent they will do so (or exclude liability as a whole) depends on their importance, but also on the scope of strict liability, that is on whether the damage can be attributed to some other person and to what extent (taking into account the predictability of damage to a reasonable person, the nature and significance of the protected values, the nature of strict liability, its basis, the usual life risks, and the reasons for which strict liability provides protection).${ }^{94}$ When a third party contributes to the occurrence of damage, it is jointly and severally liable with the operator of the dangerous activity. ${ }^{95}$ As strict liability can be excluded or limited by the actions of a third party, both the victim's contribution and his auxiliary's activity have the same significance in this matter, and this therefore represents the third basis for the exemption from strict liability. ${ }^{96}$ All aforementioned external factors must be unforeseeable and irresistible.

\section{CONClusion}

When a detailed analysis of the examined rules from the CTA, the Draft and the Principles is conducted, it is clear that all three regulatory concepts are different.

Speaking of the CTA, it can be concluded that the Serbian law, although older than the Draft and the Principles, has a view of strict liability that is more in line with contemporary trends and respects the growing

\footnotetext{
93 Art. 3:101. of the Principles.

94 Art. 3:201. of the Draft.

95 Art. 7:102. of the Draft.

96 Art. 8:101. of the Draft.
} 
importance of this form of liability. By prescribing a general case of strict liability, the CTA actually equalizes it with the fault-based liability, and that is a solution that is present in a significant number of national legal systems in the EU with the trend of growth ${ }^{97}$ and present in certain development projects, e.g. the Principles.

The Draft has opted for a different approach from the one of CTA and instead of one general case, provides specific cases where the liability for damages exists regardless of fault. By doing so, the Draft takes into account the specificities of certain dangerous objects or activities, and provides for separate, appropriate rules. This solution makes it easier to apply the rules in practice and reduces the need for interpretation.

Even though it is quite difficult to formulate a system of strict liability that would be satisfactory in all cases, the combination of the rules of the CTA and certain rules of the Draft would surely give the best results. A general case of strict liability would in principle be able to cover all cases where there is liability for damage regardless of fault, especially those who are specifically prescribed. This would ensure that the rules of strict liability will be applied whenever it is justified. On the other hand, the existence of a regulation intended for some special cases is more than useful and practical, and such rules would be applied, depending on the circumstances of each relevant case.

As explained before, the CTA provides for the general case of strict liability and several special cases, however, in our opinion, some of those special cases could be removed without any problem regarding the coherence of the strict liability's system. This refers to the liability arising from terrorist acts, public demonstrations or manifestations and liability of the event organizer because the occurrence of the damage for which someone is liable under these special norms of the CTA is very rare and the purpose of the special cases is in their usefulness. Introduction of some other special cases, such as liability for damage caused by animals and liability for damage caused by unsafe immovables is not necessary. Such cases were included in the Draft by its authors as an homage to the historical development of strict liability and beside this, there is no strong argument for their necessity. Animals and unsafe immovables are without any doubt important dangerous objects, however, we do not see any issues regarding damage caused by animals and unsafe immovables that cannot be solved under the general rules of strict liability. When discussing liability in the event of an accident caused by a motor vehi-

97 See: page 3, para. 3 and page 4, para. 1 of this paper. 
cle, we strongly believe that the Serbian law provides a better solution than the Draft. It is absolutely unacceptable that tortfeasor's fault is completely irrelevant in case of a traffic accident caused by a motor vehicle. The fault must be relevant in the legal regime that exists among motor vehicle holders on the grounds that it is not just that they are all strictly liable for the damage, if only one of them or several of them caused it on the basis of the fault-based liability.

On the contrary, the Draft can be a solid role model for Serbian legislator regarding the liability of the producer of a defective thing. First of all, the term "thing" used in the CTA is inappropriate because it considers movables and immovables, and in the sense of this case of liability, producer is liable only for the damage caused by a defective movable, i.e. defective product. Therefore, the term "product" is a better solution, as used in the Draft and in the Consumer Protection Act. Furthermore, Serbian lawmaker could consider expanding the scope of persons liable so that importer and supplier are liable in certain situations, as it is prescribed by the Draft and elaborated in this paper. The Draft is also richer than the CTA in terms of special defences. Development risks are especially of great importance and they could be introduced in the Serbian law as well, bearing in mind reasons already explained. At last, the Draft adopts a wider approach in terms of defences in all cases of strict liability, much wider than the CTA, and such approach is, in our opinion, suitable for Serbian law as well, making strict liability less strict" when it is justified.

As it can easily be concluded, certain solutions from the Draft could make the Serbian law better, while the CTA is in some other aspects still more adequate legal text than the Draft, although it is much older.

On the other hand, the Principles are not a desirable role model for the Serbian legislator. Authors of the Principles opted for the too narrow general rule of strict liability, mostly because they disagreed on how to formulate a wider one. Too rigid stance on dangerous activity, its mistaken reduction to uncommon activity, as well as the absence of specially prescribed cases of strict liability make the norms of the Principles rather unusable, so we can say with no dilemma that the Principles are not an adequate benchmark for a national legislator. It is impossible to find any rule of strict liability in the Principles which could be implemented in the Serbian law, of course without any negative presumption being made about other aspects of this legal text. 


\section{BIBLIOGRAPHY}

\section{BOOKS AND ARTICLES}

1. Battesini, E., 2015, Tort Law and Economic Development: Strict Liability in Legal Practice, The Latin American and Iberian Journal of Law and Economics, 1.

2. Dudaš, A., 2012, Od Načela evropskog ugovornog prava do Nacrta okvirnih pravila, Anali Pravnog fakulteta u Beogradu, 1.

3. Đurđev, D., 2010, Nacrt zajedničkog referentnog okvira za evropsko privatno pravo iz 2009. godine, Zbornik radova Pravnog fakulteta u Novom Sadu, 2.

4. Đurđev, D., 2013, Soft Law u evropskom komunitarnom pravu, Zbornik radova Pravnog fakulteta u Novom Sadu, 1.

5. Hodges, C., 1998, Development Risks: Unanswered Questions, The Modern Law Review, 4.

6. Jovičić, K., Vukadinović, S., 2018, Ugovorna odgovornost - pravni režimi u uporednom pravu, Teme, 2.

7. Karanikić Mirić, M., 2013, Objektivna odgovornost za štetu, Beograd.

8. Koch, B., 2009, Principles of European Tort Law, King's Law Journal, 2.

9. Linger, L., 1990, The Product Liability Directive: A Mandatory Development Risks Defense, Fordham International Law Journal, 2.

10. Lubomira Kubica, M., 2016, Origins of Strict Liability for Abnormally Dangerous Activities in the United States, Rylands v. Fletcher and a General Clause of Strict Liability in the UK, International Journal of Law and Political Sciences, 3.

11. Nikolić, D., 2016, Uvod u sistem građanskog prava, Novi Sad.

12. Pajtić, B., Radovanović, S., Dudaš, A., 2018, Obligaciono pravo, Novi Sad.

13. Principles, Definitions and Model Rules of European Private Law, Draft Common Frame of Reference (DCFR), Full Edition, Munich, 2009.

14. Salma, J., 2009, Obligaciono pravo, Novi Sad.

15. Sekulić, M., 2018, Development Risks - Definition under European Union Law and Justification for Implementation in Serbian Law, Zbornik radova Pravnog fakulteta u Novom Sadu, 2.

16. Shavell, S., 2018, The Mistaken Restriction of Strict Liability to Uncommon Activities, Journal of Legal Analysis, 1.

17. Vodinelić, V. V., 2014, Građansko pravo: Uvod u građansko pravo i opšti deo građanskog prava, Beograd.

\section{LIST OF NATIONAL REGULATIONS AND ACTS}

1. Consumer Protection Act, Official Gazette of RS, no. 62/2014.

2. Contracts and Torts Act, Official Gazette of the Republic of Croatia, no. 55/2015.

3. Contracts and Torts Act, Official Gazette of SFRY, nos. 29/78, 39/85, 45/89 - decision of the Constitutional Court of FRY and 57/89, Official Gazette of FRY, no. 31/93 and Official Gazette of SMNE, no. 1/2003 - Constitutional Charter.

4. Obligations Code, Official Gazette of the Republic of Slovenia, no. 83/2001 and $33 / 2004$. 


\title{
WEBSITE REFERENCES
}

1. Principles, Definitions and Model Rules of European Private Law, Draft Common Frame of Reference, Outline Edition, (https://www.law.kuleuven.be/personal/ mstorme/2009_02_DCFR_OutlineEdition.pdf, 15 February 2019).

2. Principles of European Tort Law, (http://civil.udg.edu/php/biblioteca/items/283/ PETL.pdf, 15 February 2019).

3. The European Civil Code Study Group, (http://hwb-eup2009.mpipriv.de/index. php/Study_Group_on_a_European_Civil_Code, 15 February 2019).

4. The European Civil Code Study Group, (https://www.asil.org/eisil/ study-group-european-civil-code, 15 February 2019).

5. The European Group on Tort Law, (http://www.egtl.org/, 15 February 2019).

6. The Research Group for Studying Existing Private Law of the European Communities, (https://www.gbz.hu-berlin.de/research/projects/existing-ec-private-law, 15 February 2019).

\section{RAZLIČITI KONCEPTI OBJEKTIVNE ODGOVORNOSTI: NACRT OKVIRNIH PRAVILA I NAČELA EVROPSKOG ODŠTETNOG PRAVA KAO UZOR SRPSKOM PRAVU?}

\author{
Miloš Sekulić
}

REZIME

U okviru Evropske unije nastali su brojni razvojni projekti u cilju harmonizacije građanskog prava država članica. Ovi projekti, nastali kao rezultat rada stručnjaka širom Evropske unije, deo su takozvanog „mekog prava" i mogu da posluže kao važan uzor domaćim zakonodavcima, uključujući i srpskog, prilikom regulisanja određenih pitanja. Razvojni projekti su u vezi sa praktično svim oblastima savremenog građanskog prava, u manjoj ili većoj meri. U ovom radu je naglasak na analizi objektivne odgovornosti za štetu kao važnom obliku odgovornosti u savremenom svetu, punom povećanih rizika za ljude i njihovu okolinu. Razmatrani razvojni projekti u ovom radu su Nacrt okvirnih pravila i Principi evropskog odštetnog prava, budući da se radi o novijim razvojnim projektima koji koriste različite koncepte prilikom regulisanja objektivne odgovornosti. Dok su se autori Nacrta okvirnih pravila opredelili za pojedinačno navođenje svih slučajeva kada se za štetu odgovara bez obzira na krivicu, autori Principa evropskog odštetnog prava su se opredelili za jedan opšti slučaj objektivne odgovornosti, prilično usko regulisan, te stoga ova dva konceptualno različita pravna akta mogu da pokažu drukčije pristupe prilikom regulisanja objektivne odgovornosti. 
Cilj ovog rada je da pokaže da li srpsko zakonodavstvo, odnosno Zakon o obligacionim odnosima koji reguliše ovaj oblik odogovornosti za štetu, može da bude unapređeno preuzimanjem rešenja iz navedenih razvojnih projekata. Zaključak autora je da se to u određenoj meri može učiniti, da je najbolji pristup kombinacija opšteg slučaja objektivne odgovornosti sa posebnim, uz uvažavanje pojedinih rešenja iz Nacrta okvirnih pravila, ali i da srpski Zakon o obligacionim odnosima ima određene prednosti $\mathrm{u}$ odnosu na pomenute razvojne projekte, naročito u odnosu na Principe evropskog odštetnog prava.

Ključne reči: Nacrt okvirnih pravila, Načela evropskog odštetnog prava, Zakon o obligacionim odnosima, opšti slučaj objektivne odgovornosti, posebni slučajevi objektivne odgovornosti.

Article History:

Received: 3 September 2019

Accepted: 28 November 2019 